\title{
Production of giant marine diatoms and their export at oceanic frontal zones: Implications for Si and C flux from stratified oceans
}

\author{
A. E. S. Kemp, ${ }^{1}$ R. B. Pearce, ${ }^{1}$ I. Grigorov, ${ }^{1,2}$ J. Rance, ${ }^{1}$ C. B. Lange, ${ }^{3}$ P. Quilty,${ }^{4}$ \\ and I. Salter ${ }^{1}$ \\ Received 25 January 2006; revised 12 July 2006; accepted 17 August 2006; published 13 October 2006.
}

[1] From a synthesis of recent oceanic observations and paleo-data it is evident that certain species of giant diatoms including Rhizosolenia spp. Thalassiothrix spp. and Ethmodiscus rex may become concentrated at oceanic frontal zones and subsequently form episodes of mass flux to the sediment. Within the nutrient bearing waters advecting towards frontal boundaries, these species are generally not dominant, but they appear selectively segregated at fronts, and thus may dominate the export flux. Ancient Thalassiothrix diatom mat deposits in the eastern equatorial Pacific and beneath the Polar Front in the Southern Ocean record the highest open ocean sedimentation rates ever documented and represent vast sinks of silica and carbon. Several of the species involved are adapted to a stratified water column and may thrive in Deep Chlorophyll Maxima. Thus in oceanic regions and/or at times prone to enhanced surface water stratification (e.g., during meltwater pulses) they provide a mechanism for generating substantial biomass at depth and its subsequent export with concomitant implications for Si export and $\mathrm{C}$ drawdown. This ecology has important implications for ocean biogeochemical models suggesting that more than one diatom "functional type" should be used. In spite of the importance of these giant diatoms for biogeochemical cycling, their large size coupled with the constraints of conventional oceanographic survey schemes and techniques means that they are undersampled. An improved insight into these key species will be an important prerequisite for enhancing our understanding of marine biogeochemical cycling and for assessing the impacts of climate change on ocean export production.

Citation: Kemp, A. E. S., R. B. Pearce, I. Grigorov, J. Rance, C. B. Lange, P. Quilty, and I. Salter (2006), Production of giant marine diatoms and their export at oceanic frontal zones: Implications for Si and C flux from stratified oceans, Global Biogeochem. Cycles, 20, GB4S04, doi:10.1029/2006GB002698.

\section{Introduction}

[2] The quantification of oceanic export production and of the sediment accumulation rate of carbon and silica are fundamental prerequisites to the understanding of biogeochemical cycling. Critical to advancing this understanding is the identification of the key processes and agents of export. Diatom algae are thought to account for over $40 \%$ of total oceanic primary production and dominate export production

\footnotetext{
${ }^{1}$ School of Ocean and Earth Science, National Oceanography Centre, University of Southampton, Southampton, UK.

${ }^{2}$ Now at Institut Universitaire Europeen de la Mer, Technopole BrestIroise, Plouzane, France.

${ }^{3}$ Department of Oceanography, Center for Oceanographic Research in the Eastern South Pacific (FONDAP-COPAS), University of Concepción, Concepción, Chile.

${ }^{4}$ School of Earth Sciences, University of Tasmania, Hobart, Tasmania, Australia.

Copyright 2006 by the American Geophysical Union. 0886-6236/06/2006GB002698\$12.00
}

[Nelson et al., 1995; Sarthou et al., 2005]. Over the last 1015 years, oceanic process studies coupled with analysis of ancient sediments have provided new perspectives on the role of large and colonial diatoms in flux to the sea floor. The temporal and spatial occurrence and variability of major oceanic diatom-driven export events have meant that conventional oceanographic survey techniques often either miss these episodic events or underestimate their significance for export [Buessler, 1998]. Furthermore, there is growing evidence that diatom blooms or aggregations within deep chlorophyll maxima (DCM) or the lower euphotic zone may generate substantial biomass and export yet much of the overall assessment of global primary production is based on satellite-derived data which only samples the top meters of the euphotic zone [Schlitzer, 2002].

[3] Significant causes of our sparse information on subsurface chlorophyll concentrations relate to shortcomings in sampling techniques which we consider in section 5 of this paper. However, it is the lack of a "species" or taxonomic approach to studies of DCMs that is a major foil to the 
proper understanding of their biogeochemistry. A measure of this lack may be had by examining papers identified by the keyword search on "Deep Chlorophyll Maximum" in the Science Citation Index. Of 143 papers that report research on marine DCMs, only 16 identify phytoplankton species.

[4] Large diatoms, simply by their size, are important for export [Goldman, 1988, 1993]. Recent research has demonstrated that several species of large or giant diatoms, hitherto thought to represent the sparse flora of oligotrophic seas have been observed in water column concentrations and major flux events and have been shown to form massive ancient sedimentary deposits [e.g., Sancetta et al., 1991; Kemp and Baldauf, 1993; Kemp et al., 2000; Yoder et al., 1994]. Several of these concentrations or deposits of diatoms appear to be associated with major oceanic frontal zones or their ancient precursors, but there has, as yet, been no synthesis of such occurrences. An improved understanding of the ecology of these "giants" and the nature of their interaction with frontal regions is essential, if key species and phytoplankton functional types are to be properly represented in ocean biogeochemical models.

[5] In earlier papers [Kemp et al., 1999, 2000; Smetacek, 2000] we documented evidence for a "fall dump" of diatom flux much of whose biomass had accumulated in DCMs. Here we revisit the evidence for production and accumulation of giant diatoms in stratified waters but also review an increasing body of evidence from both oceanographic experiments and surveys and burgeoning paleoceanographic data sets of the significance of oceanic frontal zones for generating massive diatom flux.

\section{Role of Shade Flora and Deep Chlorophyll Maxima in Production and Export}

[6] There is increasing recognition of the significance of subsurface production, both as a contributor to total production and particularly to export. An earlier summary of "shade flora" taxa by Sournia [1982] pointed to the adaptation to low light of a number of phytoplankton groups but questioned whether this was a strategy to "survive or to thrive." Subsequent research has demonstrated that species adapted to a dominantly subsurface existence in a stratified water column may reproduce rapidly in low light conditions, form substantial biomass and contribute importantly to export [e.g., Goldman, 1993; Kemp et al., 2000]. Many such species of diatoms were classically thought to characterize the sparse flora of stratified oligotrophic zones or of the summer ocean in temperate settings [e.g., Guillard and Kilham, 1978].

[7] Sancetta et al. [1991] showed widespread evidence for massive flux of rhizosolenid diatoms and Villareal et al. [1993, 1999a] documented their strategies to exploit deep nutrients including buoyancy regulation. Indeed, Rhizosolenia mats are observed to migrate between deep nutrient pools (below $100 \mathrm{~m}$ ) and the surface, thus transporting nitrate across the DCM and providing a source of new production in the surface mixed layer [Singler and Villareal, 2005; Pilskaln et al., 2005]. Observations of deep-dwelling diatoms supported by culture experiments and modeling studies have demonstrated substantial growth rates and the capability of some species (e.g., some rhizosolenids and Stephanopyxis) to bloom in low light conditions [Goldman, 1993; Goldman and McGillicuddy, 2003]. In a synthesis of the "paleo" sediment trap data available in laminated marine sediments and an appraisal of relevant recent sediment trap and other water column data, Kemp et al. [2000], demonstrated that many of the diatom species characteristic of the DCM shade flora, or otherwise adapted to stratified waters, contributed substantially to sediment accumulation, and that sedimentation in a "Fall Dump" from subsurface chlorophyll concentrations could rival or exceed that of the spring bloom. Export from such a DCM could be great, such as at times of Mediterranean sapropel formation when sedimentation of diatoms adapted to a stratified water column may account for the entire high organic carbon content of sapropels [Kemp et al., 1999; Sancetta, 1999]. Significantly, the diatoms involved in sapropel formation had previously been characterized as typical of sparse floras of oligotrophic settings. Indeed, the Mediterranean at times of sapropel formation most probably had an oligotrophic mixed layer characterized by N-fixation [Sachs and Repeta, 1999] overlying a high f-ratio DCM. It is likely that if a satellite chlorophyll sensor had tracked the Mediterranean during times of sapropel formation little surface primary production would have been recorded, while at depth, production took place that generated some of the most organic carbon-rich sediments in the geological record.

[8] A range of complementary approaches including modeling and observations are also highlighting the significance of production and export from DCMs. For example, satellite-derived productivity values for the Southern Ocean are insufficient to generate carbon export fluxes computed from nutrient distributions leading to suggestions of significant contribution to export from subsurface chlorophyll concentrations [Schlitzer, 2002]. In targeted studies of summer DCMs in temperate latitudes quantitative assessments of production through the water column are increasingly demonstrating the significance of DCM production [Prahl et al., 2005; Weston et al., 2005].

\section{Role of Oceanic Frontal Zones in Diatom Export}

[9] The following accounts summarize both modern and geological evidence for flux of giant diatoms beneath major oceanic frontal zones (Figure 1). The history of ancient diatom accumulation should be viewed in the context of the major shifts in biogenic opal sedimentation that have characterized the Neogene-Quaternary which we also summarize below.

\subsection{Modern Equatorial Pacific: Frontal Concentration and Flux}

[10] Heralded by the spectacular "line in the sea" front cover of Nature, Yoder et al. [1994] reported intense concentrations of diatoms along the North Equatorial front during the 1992 Equatorial Pacific (EqPac) JGOFS process study. The EqPac JGOFS program was formulated to address the carbon cycle in the Equatorial Pacific and, in 
the words of Murray et al. [1995], the cruises were "fortuitously" timed to sample the extreme El Niño and contrasting La Niña conditions. If the sampling of these extremes was fortuitous, then the sampling of the frontal diatom concentrations was serendipity indeed, since one of the major cruises (S2) sampled the highest chlorophyll concentrations, not at the equatorial upwelling, but associated with the leading edge of a tropical instability wave (TIW) at $2^{\circ} \mathrm{N}$ formed along the front between the cooler South Equatorial Current (SEC) water (representing the resurgent "cold tongue") and the warmer waters of the North Equatorial Counter Current [NECC]. Convergence rates of up to $40 \mathrm{~cm} / \mathrm{s}$ were recorded at the front [Yoder et al., 1994].

[11] The large surface patch dominated by the giant diatom Rhizosolenia castracanei occupied a thin surface
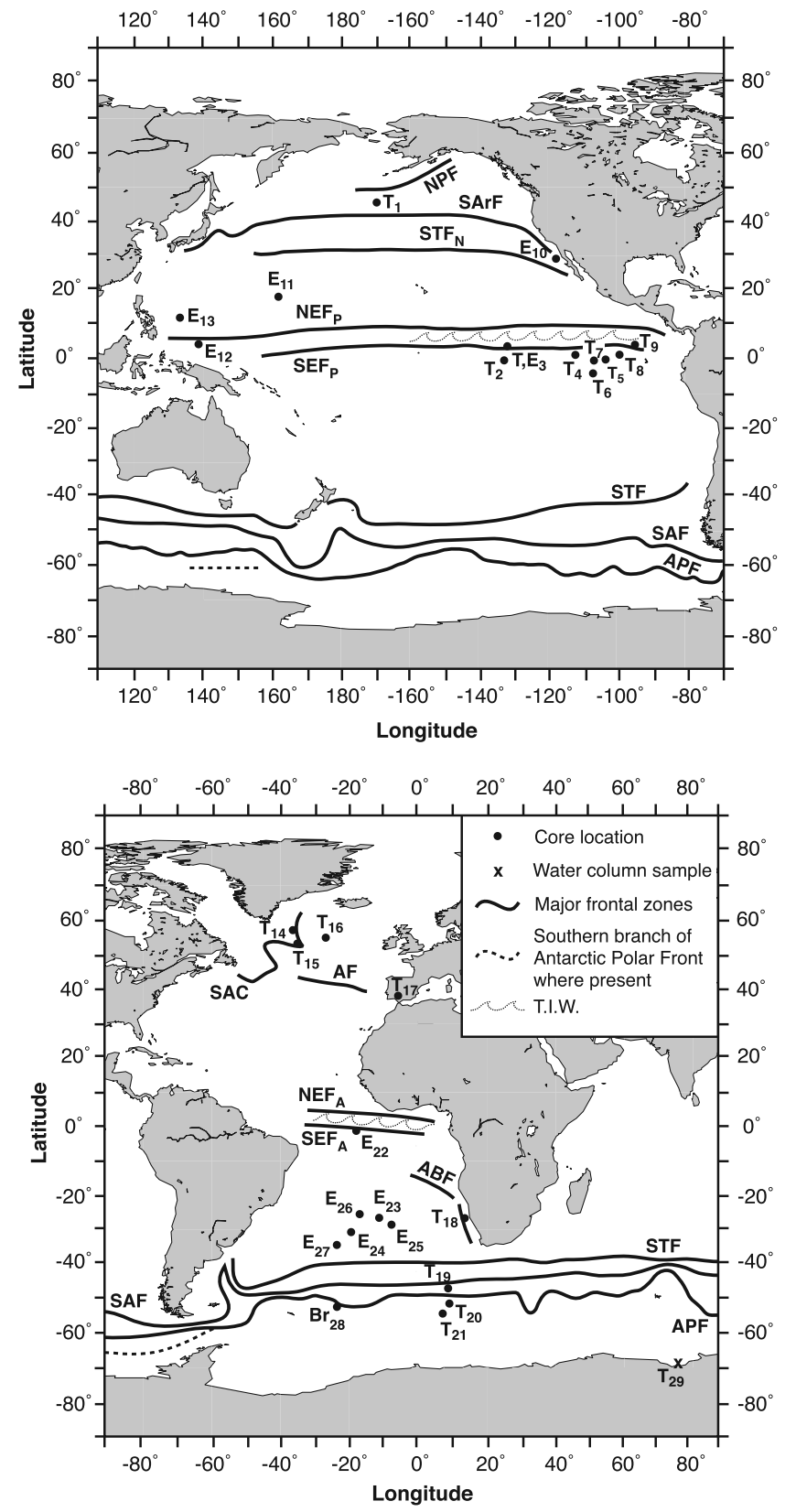

layer along the warm side of the front above the subducting SEC waters [Yoder et al., 1994]. From radiochemical (Thorium) data and nitrate budget considerations, Archer et al. [1997] deemed the diatoms to have been largely imported from the cooler SEC waters to form the surface layer on the warm side of the front. Photosynthesis was occurring in the patch apparently without nitrate utilization suggesting that the diatoms were using metabolic nitrate previously assimilated from the SEC waters [Archer et al., 1997], an explanation consistent with observations of nitrate transport to the euphotic zone by vertically migrating rhizosolenid diatoms [Villareal et al., 1993; Singler and Villareal, 2005].

[12] The diatom concentrations at the front were therefore thought to be formed in response to the subduction of the SEC waters with the buoyant rhizosolenids floating to the surface [Yoder et al., 1994]. Friedrichs and Hoffmann [2001] also argue that the localized upwelling associated with the trailing edge of the tropical instability waves introduced iron which stimulated enhanced production in the SEC waters moving towards the front. Within these waters Rhizosolenia species although qualitatively significant were not the dominant diatoms [Iriarte and Fryxell, 1995]. This reinforces arguments that it is the inherent buoyancy characteristics [Moore and Villareal, 1996] of the rhizosolenid diatoms, probably triggered by subduction at the front that has driven the formation of the diatom concentrations.

[13] Concentrations of Rhizosolenia in sea floor phytodetritus collected by the JGOFS benthic cruise (some 2 months after the observations of the front) attest to the rapid settling from the surface diatom patch [Smith et al.,

Figure 1. World map showing location of major fronts [after Orsi et al., 1995; Belkin and Gordon, 1996; Dawson and Wells, 1996; Parslow et al., 2001], regions affected by tropical instability waves (T.I.W.) and core locations described. Cores: 1, ODP Site 885/886; 2-4, DSDP Leg 85 sites 573, 574, and 572, respectively; 5-9, ODP Leg 138 sites $851,849,850,847$, and 844, respectively; 10, ODP Leg 167 Site $1010 ; 11-13$, cores described by Belyayeva [1968]; 14, EW9303-17; 15, U1304; 16, NEAP 15K; 17, Guadalquivir basin; 18, ODP Site 1084; 19-21, ODP Leg 177 sites 1091, 1093, and 1094, respectively; 22, Equatorial Atlantic Cores; 23, DSDP Site 520; 24, GeoB 3813-3; 25, GeoB 3801-6; 26, GeoB 5112-4; 27, GeoB 6425-2; 28, ODP Site 701; and 29, Prydz Bay. Note: The locations of the ODP Leg 138 cores (T5-T9) are those they occupied during laminated diatom mat deposition, backtracked positions are taken from Kemp et al. [1995]. Abbreviations: (1) Fronts: ABF, Angola-Benguela Front; AF, Azores Front; APF, Antarctic Polar Front; $\mathrm{NEF}_{\mathrm{A}}$, North Equatorial Front (Atlantic); $\mathrm{NEF}_{\mathrm{P}}$, North Equatorial Front (Pacific); NPF, North Polar Front; SAC, Subarctic Convergence; SAF, Subantarctic front; SArF, Subarctic Front; $\mathrm{SEF}_{\mathrm{A}}$, South Equatorial Front (Atlantic); $\mathrm{SEF}_{\mathrm{P}}$, South Equatorial Front (Pacific); STF, Subtropical Front; $\mathrm{STF}_{\mathrm{N}}$, Subtropical Front (Northern Hemisphere). (2) Diatom oozes: Br, Bruniopsis ooze; E, Ethmodiscus ooze; T, Thalassiothrix ooze. 
Table 1. Details of Cores Containing Giant Diatom Deposits Including References

\begin{tabular}{|c|c|c|}
\hline Core Site & Location & Reference \\
\hline ODP Site $885 / 886$ & $44^{\circ} 41^{\prime} \mathrm{N}, 168^{\circ} 16^{\prime} \mathrm{E}$ & Dickens and Barron [1997] \\
\hline DSDP Leg 85 Site 572 & $01^{\circ} 26^{\prime} \mathrm{N}, 113^{\circ} 50^{\prime} \mathrm{W}$ & Kemp et al. [1995] \\
\hline DSDP Leg 85 Site 573 & $0^{\circ} 29^{\prime} \mathrm{N}, 133^{\circ} 18^{\prime} \mathrm{W}$ & \\
\hline DSDP Leg 85 Site 574 & $04^{\circ} 12^{\prime} \mathrm{N}, 133^{\circ} 19^{\prime} \mathrm{W}$ & \\
\hline ODP Leg 138 Site 844 & $7^{\circ} 55^{\prime} \mathrm{N}, 90^{\circ} 28^{\prime} \mathrm{W}$ & Kemp et al. [1995] \\
\hline ODP Leg 138 Site 847 & $0^{\circ} 11^{\prime} \mathrm{N}, 95^{\circ} 19^{\prime} \mathrm{W}$ & \\
\hline ODP Leg 138 Site 849 & $0^{\circ} 10^{\prime} \mathrm{N}, 110^{\circ} 31^{\prime} \mathrm{W}$ & \\
\hline ODP Leg 138 Site 850 & $1^{\circ} 17^{\prime} \mathrm{N}, 110^{\circ} 31^{\prime} \mathrm{W}$ & \\
\hline ODP Leg 138 Site 851 & $2^{\circ} 46^{\prime} \mathrm{N}, 110^{\circ} 34^{\prime} \mathrm{W}$ & \\
\hline EW9303-17 & $57^{\circ} \mathrm{N}, 37^{\circ} \mathrm{W}$ & Boden and Backman [1996] \\
\hline Expedition 303 U1304 & $53^{\circ} 3^{\prime} \mathrm{N}, 33^{\circ} 31^{\prime} \mathrm{W}$ & Shipboard Scientific Party [2005] \\
\hline NEAP $15 \mathrm{~K}$ & $56^{\circ} 36^{\prime} \mathrm{N}, 27^{\circ} 81^{\prime} \mathrm{W}$ & A. E. S. Kemp and J. Rance (unpublished data, 1997) \\
\hline Guadalquivir Basin & Guadalquivir Basin, Spain & Bustillo and Garcia [1997] \\
\hline 14 cores, equatorial Atlantic Ocean & Lat. $7^{\circ} 13^{\prime} \mathrm{N}-1^{\circ} 21^{\prime} \mathrm{S}$ Long. $05^{\circ} \mathrm{W}-26^{\circ} \mathrm{W}$ & Gardner and Burckle [1975]; Stabell [1986]; Abrantes [2001] \\
\hline DSDP Site 520 & $25^{\circ} 31^{\prime} \mathrm{S}, 11^{\circ} 11^{\prime} \mathrm{W}$ & Gombos [1984] \\
\hline GeoB 3801-6 & $29^{\circ} 30^{\prime} \mathrm{S}, 8^{\circ} 18^{\prime} \mathrm{W}$ & Gingele and Schmieder [2001] \\
\hline GeoB 3813-3 & $32^{\circ} 16^{\prime} \mathrm{S}, 21^{\circ} 58^{\prime} \mathrm{W}$ & Gingele and Schmieder [2001] \\
\hline ODP Site 1084 & $25^{\circ} 30^{\prime} \mathrm{S}, 13^{\circ} 01^{\prime} \mathrm{W}$ & Lange et al. [1999] \\
\hline ODP Leg 177 Site 1091 & $47^{\circ} 68^{\prime} \mathrm{S}, 5^{\circ} 55^{\prime} \mathrm{E}$ & Grigorov et al. [2002] \\
\hline ODP Leg 177 Site 1093 & $49^{\circ} 58^{\prime} \mathrm{S}, 5^{\circ} 51^{\prime} \mathrm{E}$ & \\
\hline ODP Leg 177 Site 1094 & $53^{\circ} 10^{\prime} \mathrm{S}, 5^{\circ} 7^{\prime} \mathrm{E}$ & \\
\hline ODP Site 701 & $51^{\circ} 59^{\prime} \mathrm{N}, 23^{\circ} 12^{\prime} \mathrm{W}$ & Ciesielski et al. [1998] \\
\hline
\end{tabular}

1996]. Subsequent syntheses of both the US EqPac and French FLUPAC JGOFS studies demonstrated that particle export is enhanced during periods of TIW activity [Honjo et al., 1995; Dunne et al., 2000]. In a broadly analogous process, albeit on a less intense scale, high concentrations of Rhizosolenia diatom mats are observed in zones of converging surface currents in the eastern North Pacific gyre [Wilson et al., 2006].

\subsection{Ancient Equatorial Pacific: Evidence for Massive Neogene Flux}

[14] Leg 138 of the Ocean Drilling Program undertook a "paleo-JGOFS" N-S transect at $110^{\circ} \mathrm{W}$. One of the most significant findings was the occurrence of vast laminated diatom mat deposits of Neogene age intermittently sedimented between 15 and 4.7 Ma [Kemp and Baldauf, 1993; Kemp et al., 1995]. These mat sediments were deposited at the highest sedimentation rates ever encountered in the equatorial Pacific and record exceptionally high opal and carbon flux rates (Table 1). They are composed dominantly of mats of Thalassiothrix longissima although occasional concentrations of rhizosolenids also occur [Pearce et al., 1995] (Figure 2). Both Yoder et al. [1994] and Kemp et al. [1995] argued that these Neogene mat deposits originated from the sinking of surface concentrations generated by Tropical Instability Wave activity by the same mechanisms as those that generated the 1992 Rhizosolenia concentrations. From investigations of previous Deep Sea Drilling Program (DSDP) cores, it is clear that these deposits extended over at least $3500 \mathrm{~km}$ of longitude and some up to $5000 \mathrm{~km}$. Such is their prominence on seismic sections that individual horizons may be traced in the subsurface for distances of up to $5000 \mathrm{~km}$ [Bloomer and Mayer, 1997].

\subsection{Southern Ocean Giant Diatom Deposits}

[15] Previously held views that the elevated accumulation rates of biogenic opal in the Southern Ocean were due to high burial efficiency have been superseded by a consensus that high rates of opal flux from the surface are responsible [Pondaven et al., 2000; Sigmon et al., 2002]. Thus the scientific focus for understanding this has firmly shifted to the examination of surface water processes.

\subsubsection{Modern Southern Ocean}

[16] Although much of the surface waters of the Southern Ocean are regarded as one of the prominent HNLC (high nitrate; low chlorophyll) regions, evidence from recent surveys have demonstrated elevated production in the region of the Antarctic Polar Front [e.g., Quéguiner et al., 1997; Bathmann et al., 1997]. Earlier cruises observed high concentrations of both Fragilariopsis kerguelensis and Corethron spp. associated with the Polar Front. However, in the most intensive study undertaken to date, during the 1995/1996 Polarstern cruise, a finescale survey of a portion of the polar front documented three dominant species complexes [Smetacek et al., 2002]. Pseudo-nitzschia was widely distributed and Chaetoceros species characterized the frontal jet, however Thalassiothrix was concentrated north of the frontal jet where overall phytoplankton and chlorophyll were highest and with concentrations in the lower part of the mixed layer approximately double those at the surface [Klaas et al., 1997]. Smetacek et al. [2002] proposed that the Thalassiothrix accumulations were promoted by its robust grazer protection. Tremblay et al. [2002] documented low production rates in lower-Si waters north of the frontal jet and inferred slow accumulation rather than a "bloom" for the Thalassiothrix abundance, also highlighting its heavily silicified robust frustule. While grazer protection may have played a part, the presence of Thalassiothrix on the northern (warmer) side of the front above subducting waters is analogous to the position of the Rhizosolenia accumulations observed at the equatorial $\mathrm{Pa}-$ cific front. Intriguingly, an investigation of diatom sinking rates during the SOIREE iron enrichment experiment [Waite and Nodder, 2001] demonstrated positive buoyancy in the 

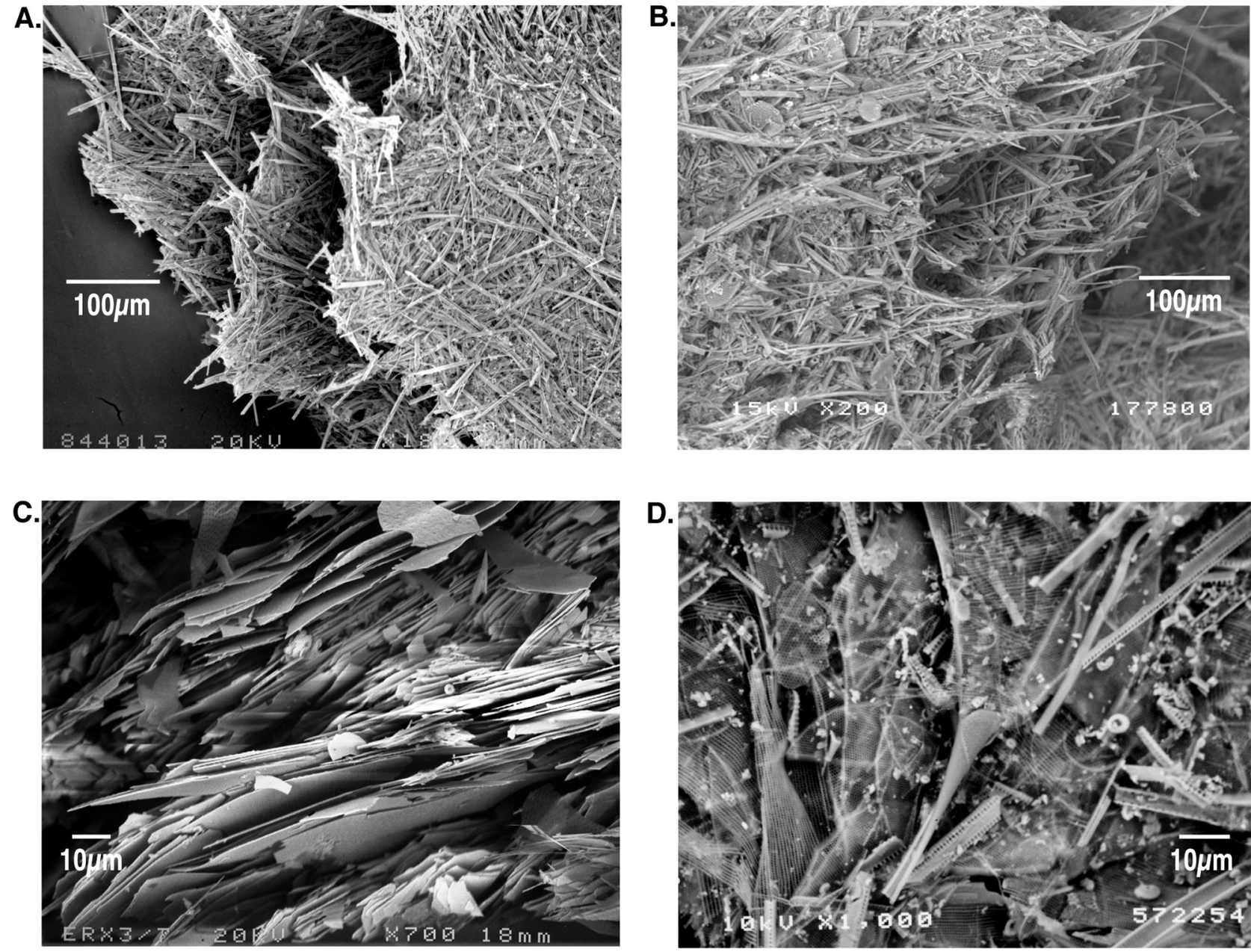

Figure 2. SEM images of giant diatom deposits. (a) Thalassiothrix longissima diatom mats from Neogene age sediments, Eastern Equatorial Pacific Ocean, ODP Leg 138; (b) Quaternary age Thalassiothrix antarctica diatom mats, ODP leg 177; (c) Ethmodiscus rex diatom fragments, from Miocene age sediments, DSDP Site 520; (d) Rhizosolenia diatoms from Neogene age sediments, Eastern Equatorial Pacific, ODP Leg 138.

case of Thalassiothrix, analogous to that displayed by rhizosolenid diatoms and Ethmodiscus rex [Moore and Villareal, 1996].

[17] A recurrent and seasonally persistent DCM has been identified between two branches of the polar front in the Australian sector [Parslow et al., 2001]. This develops initially at $60 \mathrm{~m}$ in spring/early summer but by late summer (March) is at $100 \mathrm{~m}$ depth. Between 70 and $80 \%$ of the carbon within this DCM was accounted for by large diatoms including Thalassiothrix and rhizosolenids [Kopczynska et al., 2001] and this coincided with a deep maximum in biogenic silica production [Quéguiner, 2001].

[18] Deep chlorophyll concentrations down to $60 \mathrm{~m}$ were documented in the November-December 1992 (Austral spring) Sterna survey between branches of the Polar Front from $65^{\circ} \mathrm{S}$ to $68^{\circ} \mathrm{S}$ in the Bellingshausen Sea along $85^{\circ} \mathrm{W}$ [Boyd et al., 1995]. Larger diatoms dominated and species noted at the surface included Thalassiosira, Rhizosolenia and Chaetoceros although there were not detailed studies of diatom floras.
[19] Most of these recent detailed physical/biogeochemical studies have identified more than one branch of the Polar Front separated by up to $5^{\circ}-7^{\circ}$ [Pollard et al., 2002]. Parslow et al. [2001] refer to the zone between branches of the Polar Front as the "Inter-Polar Front zone" IPFZ, and where studied, it commonly contains a DCM that may develop and deepen from austral spring through summer. Within the IPFZ silicate may become limiting although nitrate does not, so that diatom production may be confined to a DCM in this region. The surface waters of such regions therefore fit the Dugdale et al. [1995] criteria as HNLSLC (High Nitrate-Low Silicate, Low Chlorophyll).

[20] The most spectacular manifestation of a Southern Ocean DCM described to date is the seasonally recurrent patch observed above the shelf edge in Prydz Bay [Quilty et al., 1985] (Figure 3). The patch exceeded $8.5 \mathrm{~km}$ in N-S extent and lay at depths between 85 and $165 \mathrm{~m}$ within the dicothermal layer. Samples taken from the zone of the echo with Bongo nets showed it to comprise intertwined 3- to 4-mm-long cells of Thalassiothrix antarctica (Figure 3) 


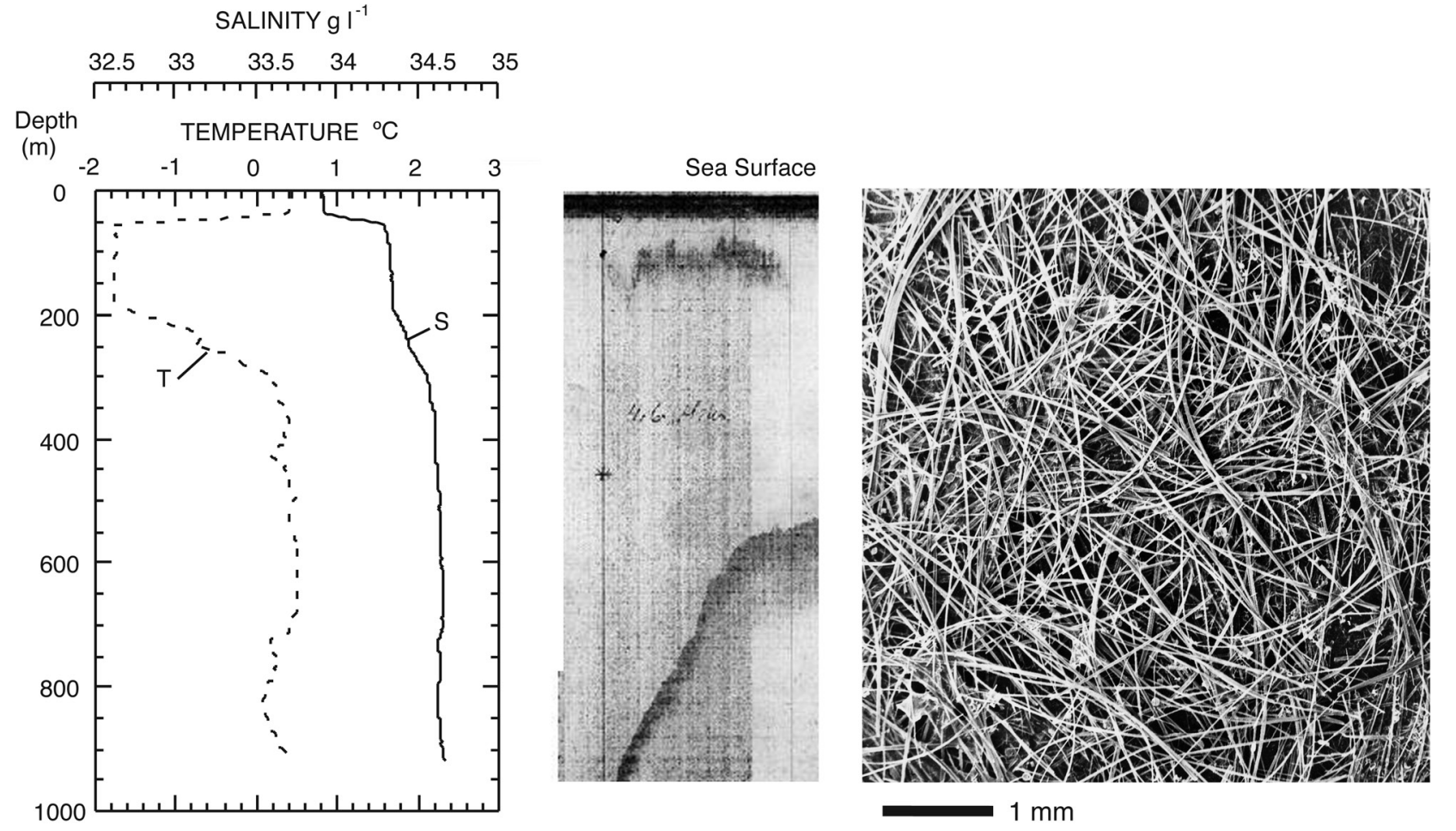

Figure 3. Seasonally recurrent diatom patch off Prydz Bay with hydrography and SEM image of tangled mass of Thalassiothrix antarctica recovered in Bongo nets. The patch was sampled on 14 February 1982 at $66^{\circ} 38^{\prime} \mathrm{S}, 72^{\circ} 57^{\prime} \mathrm{E}$. Compare SEM image with those of Figures $2 \mathrm{a}$ and $2 \mathrm{~b}$. SEM image is courtesy of Gustaaf Hallegraeff.

with very minor associated rhizosolenids [Hallegraef, 1986]. It is worth emphasizing that the observation of this diatom patch was serendipitous and relied on the echo sounding.

[21] Advection of waters of the Permanently Open Ocean Zone (POOZ) or the Inter-Polar Polar Front Zone (IPFZ) northward to the polar front occur at mean rates of around $1 \mathrm{~cm} / \mathrm{s}$ [Strass et al., 2002], an order of magnitude less than convergence rates at the equatorial Pacific front. However, meander structures within the front may locally raise these [Naveiro Garabato et al., 2002]. The overall pattern is therefore similar to that of the equatorial Pacific (and equatorial Atlantic; see below) with substantial volumes of surface waters progressively encountering the fronts.

\subsubsection{Ancient Southern Ocean}

[22] Assessment of core top diatom floras reveals a close association of Thalassiothrix with the zone beneath the present Polar Front [Zielinski and Gersonde, 1997]. The first ODP Leg (177) to undertake deep piston coring in the region of and south of the location of the modern Polar Front recovered thick Quaternary Thalassiothrix antartica deposits several of which were laminated and deposited at average bulk sedimentation rates of $250 \mathrm{~m} / \mathrm{m}$.y., the highest open ocean pelagic sedimentation rates ever recorded [Shipboard Scientific Party, 1999]. These laminated diatom mat deposits resemble those of the Neogene equatorial Pacific sediments cored on ODP Leg 138 (Figure 2). An electron microscope study of resin-embedded sediment reveals a possible annual lamina couplet/triplet sequence suggesting maximum sedi- mentation rates as high as $80 \mathrm{~cm} / \mathrm{k} . \mathrm{y}$. during the most intense episodes of mat deposition [Grigorov et al., 2002]. Further evidence of an earlier history of massive diatom sedimentation occurs at DSDP Site 701, just north of the present location of the Polar front which contains a 14.7-m-thick, near-monospecific ooze of the giant diatom Neobrunia of late Miocene age (Figures 1 and 2) [Ciesielski et al., 1998].

\subsection{Evidence From Other Ancient Diatom Deposits \\ 3.4.1. North Atlantic Thalassiothrix Diatom Mat Deposits}

[23] Since description of the laminated Thalassiothrix diatom mat deposits of the equatorial Pacific [Kemp and Baldauf, 1993] there have been several other accounts of analogous sediments, mostly similarly linked to frontal activity (Figure 1). In the northern North Atlantic, a 3-m-thick Thalassiothrix longissima diatom mat deposit was sedimented, probably in Isotope Stage 5e beneath the subarctic convergence (SAC) [Boden and Backman, 1996]. Most recently, IODP Leg 303 cored extensive Thalassiothrix deposits of Pleistocene age including some concentrated laminated intervals up to $8 \mathrm{~m}$ thick at Site 1304 north of the Charlie Gibbs fracture zone (Figure 1), again beneath the present location of the SAC [Shipboard Scientific Party, 2005]. Similar but thinner mat deposits of Holocene age were recovered from RRS Darwin core NEAP $15 \mathrm{~K}$ (Table 1 and Figure 1). Other studies have documented intervals during the Holocene dominated by the rhizosolenid Rhizosolenia borealis and attributed these to 
record proximity to the Subarctic Front [Andersen et al., 2004].

3.4.2. Benguela Current System Thalassiothrix Diatom Mat Deposits

[24] ODP Leg 175 documented the existence of intervals of peak opal flux dominated by Thalassiothrix antarctica, in particular during an "early Matuyama diatom maximum" $(2.6-2.0 \mathrm{Ma})$ in which concentrations commonly form a tangled meshwork within the sediment [Lange et al., 1999]. These deposits are interpreted to have formed beneath the frontal boundary between the cold upwelled water and the offshore warmer South Atlantic surface water during episodes of equatorward excursions of subantarctic waters, possibly also related to enhanced North Atlantic Deep Water production [Berger et al., 2002].

3.4.3. Giant Diatom Oozes of the Equatorial Atlantic

[25] Sediment concentrations of the giant (up to $2 \mathrm{~mm}$ diameter) diatom Ethmodiscus rex have been documented in many cores from the equatorial Atlantic occurring at intervals through the late Pleistocene. Earlier views on the origin of these layers of this typically sparsely occurring solitary diatom, characteristic of warm oligotrophic waters included massive short-lived blooms [Gardner and Burckle, 1975] or concentration by differential dissolution [Mikkelsen, 1977]. In fact, oceanographic investigations show that $E$. rex is adapted to survival in the open ocean through vertical migration to exploit deep nutrient pools and is not a "bloom" species [Villareal et al., 1999b], while E. rex has also been shown not to be dissolution resistant [Lange et al., 1994]. In a recent reappraisal, Abrantes [2001] following an earlier suggestion of Kemp [1994], ascribed these deposits to the action of frontal zones. In fact, TIWs, analogous to those of the equatorial Pacific also occur in the equatorial Atlantic with similar consequences for biological/physical interaction [Menkes et al., 2002]. Intense intervals of $E$. rex accumulation through the late Pleistocene are ascribed to intervals of strong African monsoons resulting in enhanced run-off of silica-rich waters which promoted $E$. rex growth, although its subsequent selective concentration and mass sedimentation was controlled by the TIW activity [Abrantes, 2001]. This is consistent with current ecological and biogeochemical data on this species [Villareal et al., 1999b].

\subsubsection{Giant Diatom Oozes of the Central South} Atlantic

[26] The occurrence of near monospecific oozes of Ethmodiscus rex in Pleistocene (Meteor cores [Gingele and Schmieder, 2001; Romero and Schmieder, 2006; C. B. Lange, unpublished data, 2001]) and late Miocene (DSDP 520 [Gombos, 1984]) sediments of the central South Atlantic are a potentially more enigmatic occurrence. These locations are all close to the middle of the South Atlantic gyre, and, apparently unrelated to an obvious major convergent zone.

\subsubsection{Giant Diatom Oozes of the Tropical and Subtropical Pacific Ocean}

[27] The widespread occurrence of Ethmodiscus rex oozes from shallow cores in the western tropical Pacific Ocean are described by Belyayeva [1968]. Frontal convergence along the boundary of the Northern Equatorial Current might be expected to occur within this region, leading to concen- trations of these diatoms in the sediments. In addition, the authors have observed the presence of reworked Ethmodiscus ooze in early Pliocene sediments at DSDP Site 574, where a similar frontal concentration mechanism to that described for Neogene laminated diatom mat deposits is likely (see section 3.2). An Ethmodiscus diatom ooze is also documented from Miocene-early Pliocene age sediments in the subtropical eastern Pacific Ocean at ODP Site 1010, the genesis of this ooze is attributed to the movement of surface ocean fronts associated with the California Current [Pike, 2000].

\subsubsection{North Pacific Thalassiothrix Oozes}

[28] A rapidly deposited late Miocene-early Pliocene diatom ooze dominated by Thalassiothrix and Thalassionema was documented in the North Pacific. Dickens and Barron [1997] relate this occurrence to physical concentration of diatoms at the overlying northern polar front along the boundary of the subarctic and central Pacific water masses with the timing generated by enhanced nutrient input and/or a change in atmosphere/ocean dynamics.

\section{Shifts in Deposition of Giant Diatoms Through Time and Relation to Opal Sedimentation Shifts in the World Ocean}

[29] An examination of the temporal occurrence of giant diatom deposits reveals changes in the occurrence which mimic previously identified broad shifts in oceanic opal sedimentation [Baldauf and Barron, 1990; Cortese et al., 2004]. For example, a cessation of diatom mat deposition in the eastern equatorial Pacific is followed by the onset of diatom mat deposition beneath the Polar Front in the Southern Ocean (Figure 4). On a higher resolution, and on the basis of the presently available age data, there does not appear to be a simple relationship with glacial-interglacial cycles but rather there may turn out to be a relationship with silica supply, either through input, for example, from meltwater, and/or through changes in deep and intermediate water circulation.

[30] The occurrence of Pleistocene Thalassiothrix oozes in the northern North Atlantic goes against the current Holocene deep-water circulation that favors the Si-poor North Atlantic as a "carbonate" ocean [Berger, 1970]. These episodes of diatom production must have been fueled by major episodes of input of silica to the ocean, possibly in pulses of meltwater.

\section{Discussion}

\subsection{Giant Diatoms and Fronts: A Summary}

[31] Giant diatoms including Rhizosolenia spp. Ethmodiscus rex and Thalassiothrix spp., most of which appear to be capable of buoyancy regulation are prone to concentration at major ocean fronts where they subsequently sediment massively. Ancient episodes of Thalassiothrix deposition in the equatorial Pacific and Southern Ocean represent the highest open-ocean pelagic sedimentation rates ever recorded. It appears that such diatoms may not be the dominant species in the waters moving towards the front (although major subsurface concentrations have been docu- 


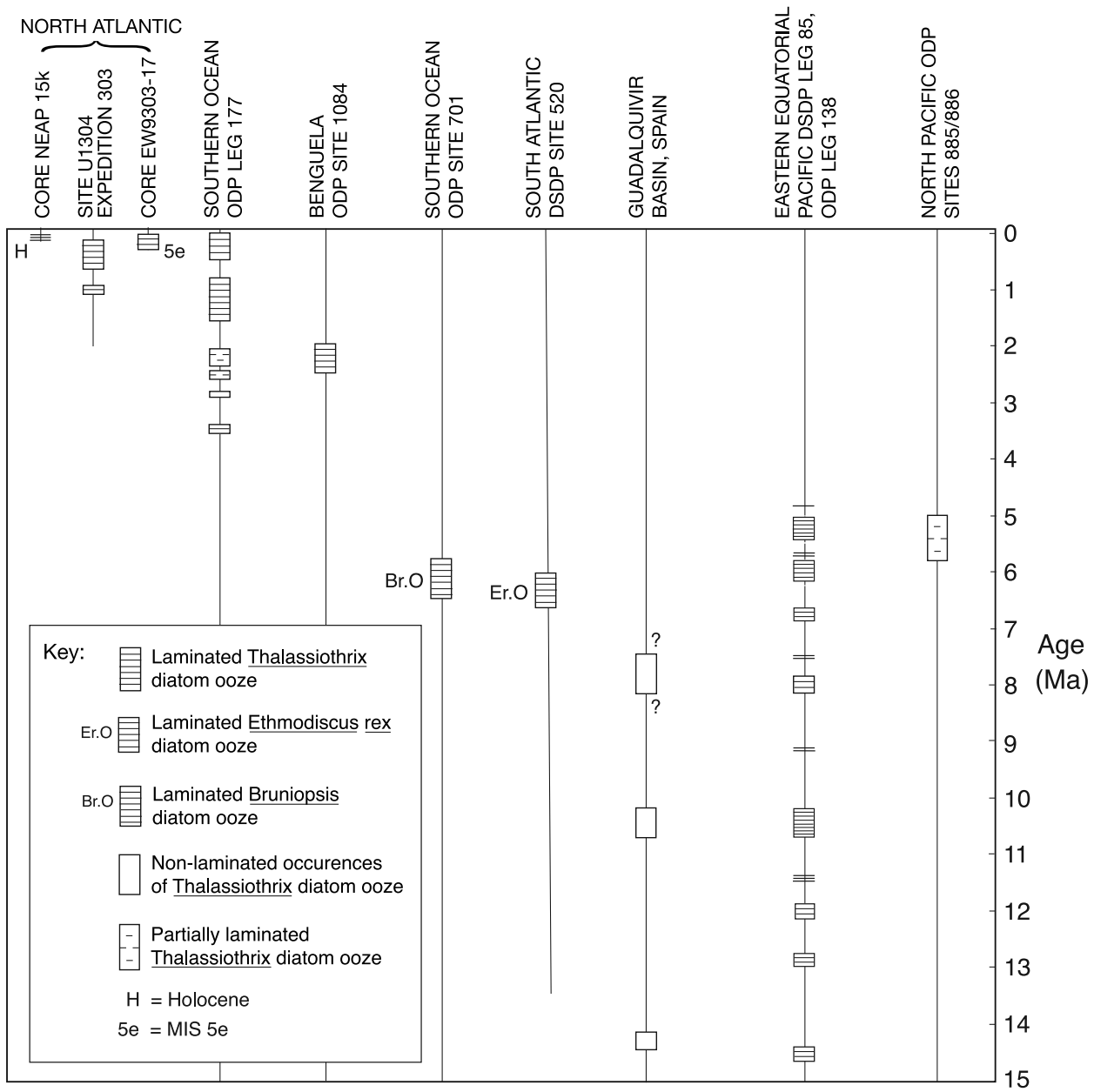

Figure 4. Occurrence of Miocene-Quaternary age giant diatom deposits in the North Pacific Ocean, Eastern Equatorial Pacific Ocean, Southern Ocean, and North and South Atlantic oceans.

mented) but are subsequently concentrated, usually on the warm side of the front (Figure 5) and sediment massively often dominating the export.

[32] The input of nutrients along fronts, for example in the Southern Ocean due to meanders of the Polar Front [Naveiro Garabato et al., 2001], or in the equatorial Pacific by upwelling at the trailing edge of TIWs [Friedrichs and Hoffmann, 2001] may also contribute to the increase in diatom biomass. However, conventional blooms, such as those characterized in the equatorial Pacific, equatorial Atlantic and Southern Ocean by Pseudo-nitschia and other lightly silicified species are rarely found in the sediment due to dissolution effects [Lange et al., 1994; Abrantes and Moita, 1999; C. B. Lange unpublished data, 2006]. Significantly, a recent synthesis of iron enrichment experiments emphasizes the importance of the giant diatoms and, intriguingly, in one experiment (SERIES), Thalassiothrix was reported as a bloom species by de Baar et al. [2005] attaining concentrations of 12,100 cells per liter. What is certain is that our present state of understanding of the ecology of these giant diatoms is woefully inadequate and as we summarize below, it will take some effort to remedy this.

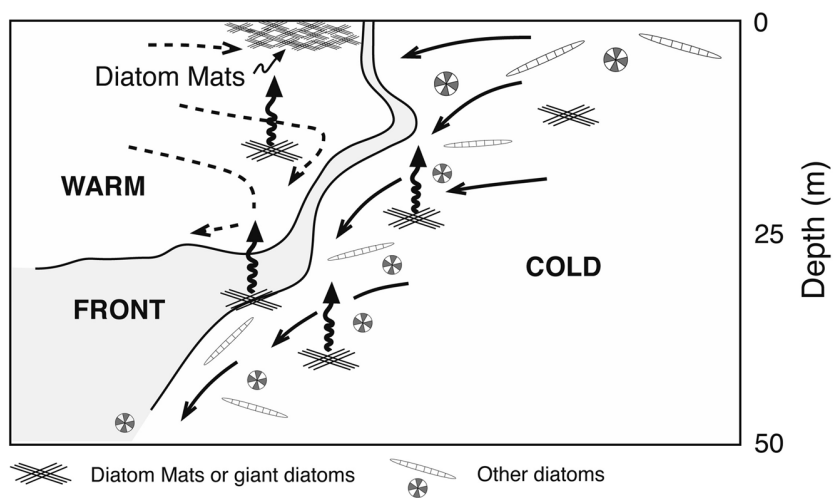

Figure 5. Schematic showing concentration of giant diatoms/diatom mats in fronts adapted from Yoder et al. [1994]. 


\subsection{Shortcomings in Oceanographic Sampling Methods}

\subsubsection{Sampling Deep Chlorophyll Maxima}

[33] On one of the earliest oceanographic expeditions, the Valdivia cruise of 1898-1899, Wilhelm Schimper deployed closing nets to sample the deeper parts of the ocean surface waters and used the term "Schattenflora" (shade flora) to describe the characteristic plankton identified. Subsequent research on these samples showed that a number of key species of large diatoms were an important component of this deep-dwelling community [Karsten, 1905]. Sournia [1982] reviewed evidence for the existence of a shade flora. However, very few studies specifically targeting the microor meso-phytoplankton of the DCM have taken place. Through technological advances, for example, in sensors for pigments and for sampling pico-plankton (e.g., FRFF, Flow cytometry) these are increasingly routinely measured, but there has been no parallel move to routine sampling and identification of larger phytoplankton species.

\subsubsection{Sampling Giant Diatoms: Size Considerations}

[34] In consideration of the size-selectivity of oceanographic sampling techniques, it is instructive to refer to an account of the standard size classification in a biological oceanography textbook where the constituents of the class size $0.2-20 \mathrm{~mm}$, "Mesoplankton" are referred to as "Mostly Zooplankton" [Miller, 2004]. In this context it is worth emphasizing that diatoms range across 3 orders of magnitude in size [Smetacek, 2000] and that all the very large and giant diatoms fall into the $0.2-20 \mathrm{~mm} /$ Mesoplankton size class. In fact, for the large or giant diatoms, sampling techniques appropriate to zooplankton (i.e., nets) must be deployed. Thus oceanographic surveys will routinely under sample giant diatoms. For example, in the SOIREE experiment the zooplankton nets became clogged with giant diatoms [Zeldis, 2001]. It is likely that bottles will not act as good samplers of diatom aggregates or mats because of the aperture size and arrangement of the end stopper. Sediment traps, with a grid (typically $20-25 \mathrm{~mm}$ ) over the funnel to prevent turbulence will also not be capable of sampling large tangled masses or mats (e.g., Figure 3). While some modern oceanographic studies have included analysis of chlorophyll and pigment concentrations, few have encompassed the routine sampling of micro-phytoplankton (or, indeed, meso-plankton) from different depth levels.

[35] Difficulties with direct water column observation and sampling of diatom mats or giant diatom aggregates have been highlighted by complementary deployment of divers (limited to 0-20 $\mathrm{m}$ depth) and a video plankton recorder in the North Pacific Gyre [Villareal et al., 1999a]. In these studies, small diatom mats were invisible to divers due to poor contrast. With the video plankton recorder the more restricted volume sampled misses some large mats (otherwise observed by divers) [Villareal et al., 1999a].

\subsection{Ecological Knowns and Unknowns}

\subsubsection{Diatom Adaptation to Stratified Waters}

[36] Classically, diatoms have been characterized as dominant in turbulent, fertile waters but subordinate to other phytoplankton such as dinoflagellates in (surface water) nutrient exhausted stratified environments [Margalef,
1978]. The burgeoning evidence, summarized above, from both modern oceanographic experiments and "palaeo-flux" studies of ancient sediments requires a reappraisal of this, in that there are species of diatoms that are not only adapted to survive in stratified conditions, but that may also form significant biomass and may dominate flux from such environments.

[37] Diatoms exhibit three adaptations to stratified conditions with associated nutrient depleted mixed layers. Several species are capable of reproducing rapidly in low light conditions characteristic of the lower part of the surface mixed layer and even at the nutricline [Goldman, 1993; Goldman and McGillicuddy, 2003]. Other species, either as individual cells or as mats, are able to regulate their buoyancy to take up nitrate from the nutricline and ascend to surface waters to photosynthesize [Singler and Villareal, 2005; Villareal et al., 1999b]. A further adaptation is the association with intracellular N-fixing cyanobacterial symbionts particularly with Hemiaulus [Carpenter et al., 1999; Scharek et al., 1999], although blooms of this species are observed within the mixed layer and it is not documented to occur at frontal zones.

[38] Although several of the stratified-adapted species discussed are capable of rapid reproduction in conventional blooms, the growth of biomass commonly appears to involve a more gradual accumulation (within DCMs or at fronts). In this respect the large, heavily silicified or "armored" nature of some species or their formation of large mats, both adaptations that inhibit grazers, are an inherent part of this strategy [Hamm et al., 2003; Smetacek et al., 2004]. In this respect they are totally different from the well documented more lightly silicified and rapidly growing diatoms of the spring bloom or coastal upwelling pulse whose strategy appears to be to grow and sediment rapidly in a matter of days before zooplankton populations can increase sufficiently for substantive grazing to occur [Alldredge and Gotschalk, 1989].

\subsubsection{Vertical Migration}

[39] Of the diatoms discussed, studies by Villareal and others demonstrate that large individual cells of Ethmodiscus rex, and both individual cells and mats of rhizosolenid diatoms are able to regulate their buoyancy to migrate between deep nitrate pools (as deep as $140 \mathrm{~m}$ ) and the surface [Villareal et al., 1993, 1999a; Moore and Villareal, 1996; Singler and Villareal, 2005; Pilskaln et al., 2005]. At present, the ecology of Thalassiothrix has not been wellstudied, either in the field or in culture, although there is one report of positive buoyancy in shipboard cultures [Waite and Nodder, 2001]. The extent to which vertical migration may be an important part of Thalassiothrix ecology therefore remains unknown.

\subsubsection{Massive Concentration at Depth}

[40] The most striking evidence for intense concentration at depth is that of Quilty et al. [1985] (Figure 3). The spatial and temporal abundance of such concentrations is unknown, although evidence from the sediment suggests that such accumulations must episodically have been common to generate observed sediment deposits [Kemp et al., 1999]. Deep sound-scattering layers are relatively common, although very sparsely sampled and it may be that other such 
Table 2. Silicon and Carbon Mass Accumulation Rates for Giant Diatom Deposits ${ }^{\mathrm{a}}$

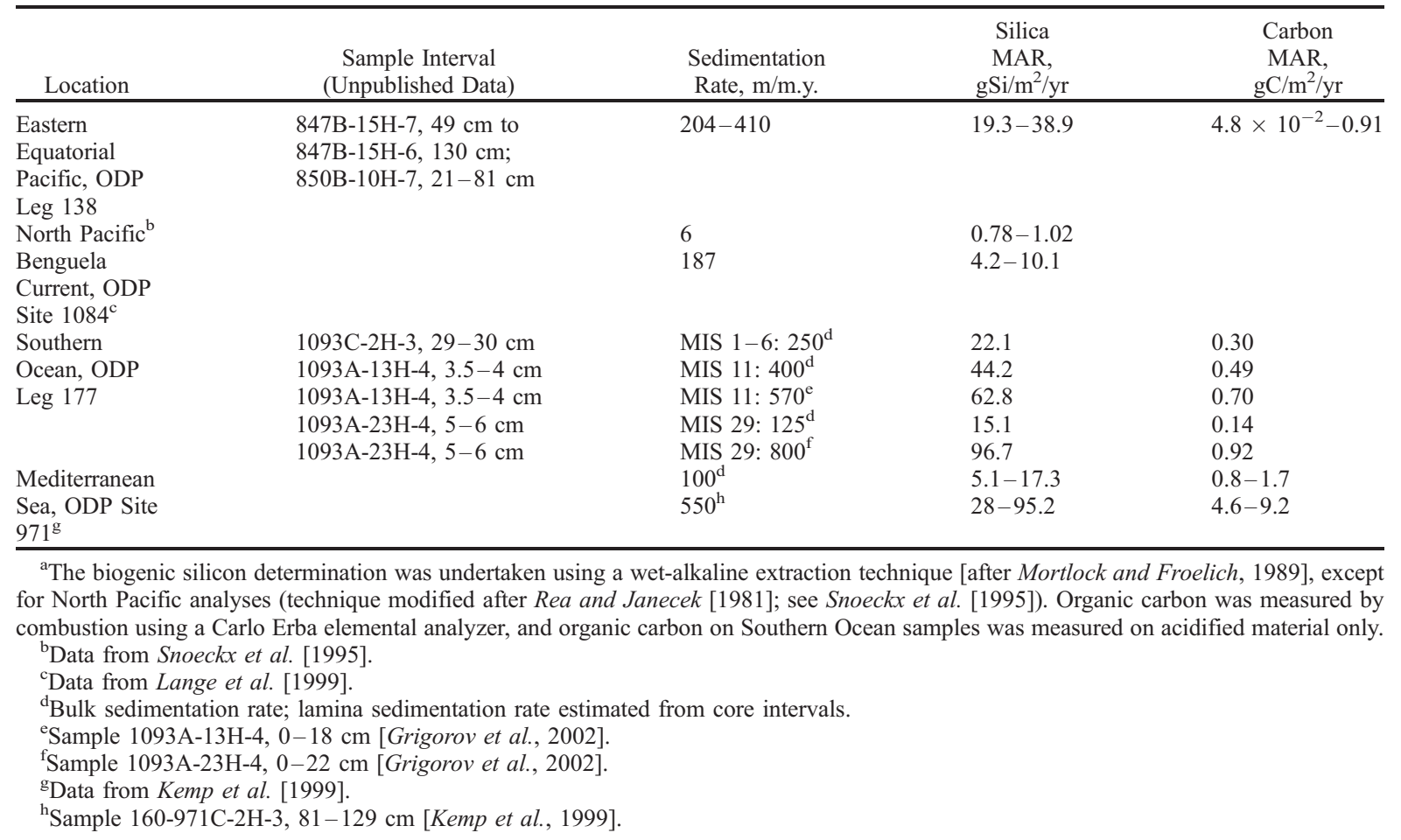

layers are generated by giant diatoms rather than zooplankton or fish [cf. Barber and Haedrich, 1969].

\subsection{Implications for the Definition of Phytoplankton "Functional Types" in Global Ocean Biogeochemistry Models}

[41] Biogeochemical models are increasingly including different phytoplankton functional types in order to give appropriate representation of the contrasting interaction with different nutrients and physical water column conditions observed. However, recent reviews represent the diatoms as a single "functional type" [e.g., Anderson, 2005; Le Quéré et al., 2005] while others continue to regard diatoms to be unfavored in stratified conditions [Hood et al., 2006]. On the basis of the evidence presented here, we propose that a separate diatom functional type should be adopted in models; one that is adapted to stratified waters and capable of exploiting deep nutrient sources to produce significant biomass and export.

\subsection{Significance for Climate Change and Biogeochemical Modeling}

[42] As Bopp et al. [2005] aptly put it: "Because of their prominent role in biogeochemical cycles, the response of diatoms to climate change may be essential to understanding future carbon cycle behaviour." Models of global change with increasing $\mathrm{CO}_{2}$ levels show increased stratification of surface waters particularly in the Southern Ocean [Manabe and Stoufer, 1993]. Initial coupled modeling with simple ocean carbon models [Sarmiento et al., 1988] showed decreased carbon flux with increased stratification, a result corroborated using more sophisticated biological models including phytoplankton [Bopp et al., 2001]. Using a model specifically targeted at the response of diatoms, Bopp et al. [2005] conclude that increased stratification and nutrient depletion in surface waters favors small phytoplankton at the expense of diatoms. However, this model used a single diatom functional type, and furthermore, was calibrated by satellite chlorophyll concentrations, thus taking no account of the possible contribution of subsurface diatom production.

[43] Until proper account is taken of the scale of production and export from the subsurface and "twilight" zone, models will not adequately address the reaction of ocean biogeochemistry to climate change. The evidence presented here of a group of diatoms adapted to stratified conditions and capable of generating significant and even exceptional flux (Table 2) suggests that model prediction of reduced export with increased stratification must be treated with skepticism. Indeed, the reverse may apply.

\subsection{Implications for Paleoceanographic Interpretations}

[44] The presence of sediment concentrations of the species of giant and mat-forming diatoms discussed in this paper may be used as indicators of "paleo-" oceanic frontal position. Abundance of these species may also be used as evidence for the availability of enhanced nutrients, especially silica, but within stratified conditions, for example as would occur during glacial meltwater pulses. Within the expanded, Southern Ocean Pleistocene record at ODP Site 1093, laminated diatom mat deposits tend to occur during transitional or inter-glacial episodes, although the detailed chronology is hampered by the lack of carbonate for isotopic chronologies. 
[45] There is increasing use of ${ }^{30} \mathrm{Si}$ and ${ }^{15} \mathrm{~N}_{\text {diatom of }}$ diatom opal as indicators of past nutrient utilization [e.g., Crosta et al., 2005]. At present there have been few attempts to isolate individual diatom species for deriving these so that a bulk diatom opal is used. Given the difference that might be expected in isotope ratios between surface and deep-dwelling diatoms, interpretations of the bulk diatom isotope signal should be treated with caution [De La Rocha, 2006].

\section{Conclusions}

[46] Giant diatoms and diatom mats, largely hitherto thought to be sparse phytoplankton of oligotrophic oceans or in terms of biogeochemical significance "curiosities," are shown to be concentrated at, and sediment massively beneath, oceanic frontal zones. Such diatoms may not be dominant in the waters approaching the fronts but are disrupted and concentrated at frontal zones, generally accumulating on the warm side of the front before sedimenting. Many of these species are shown to be adapted to stratified waters and are capable of exploiting deep nutrient sources either by buoyancy regulation or the ability to bloom in low-light conditions. Their large and robust frustules or the formation of large mats provide defense against grazers. Several recent oceanographic studies have emphasized the overlooked nature of these giant diatoms for nutrient cycling and production in the ocean and the complementary evidence from recent and ancient oceanic sediments presented here emphasizes their importance for ocean flux.

[47] For too long there has been a "black box" approach to biological oceanography. There is now a realization of the importance of a species-based approach particularly as regards significance for export. Identification of the key species and functional types is essential, not only for our understanding of biogeochemical processes, but critically to underpin the modeling of the effects of climate change on the ocean carbon cycle.

[48] Many oceanographic surveys appear to be sampling a spatially restricted and size selective steady state that overlooks some of the key species and export events that drive biogeochemical cycles. We urgently need to sample these and, as Le Quéré et al. [2005] succinctly put it "Much more field observations are needed," It is, perhaps, stating the obvious that we must look in the right place in the oceans to observe the biogeochemically important processes, but we also need to look using methods that will effectively sample the key players in these processes.

[49] Acknowledgments. Funding for this research was provided by the Natural Environment Research Council (UK) through grants GST/02/ 252 and JREI F/S/2000/00123 to A. E. S. K. and R. B. P. and through a NERC Research Studentship to I. G. Elaine Watson is thanked for drafting figures. We acknowledge discussions with Alberto Naveiro Garabato, Andreas Oschliess, and Duncan Purdie, whose comments also improved the manuscript.

\section{References}

Abrantes, F. (2001), Assessing the Ethmodiscus ooze problem: New perspective from a study of an eastern equatorial Atlantic core, Deep Sea Res., Part I, 48, 125-135.
Abrantes, F., and M. T. Moita (1999), Water column and recent sediment data on diatoms and coccolithophorids off Portugal confirm sediment record of upwelling events, Oceanol. Acta, 22, 319-332.

Alldredge, A. L., and C. C. Gotschalk (1989), Direct observations of the mass flocculation of diatom blooms: Characteristics, settling velocities and formation of diatom aggregates, Deep Sea Res., 36, 159-171.

Andersen, C., N. Koc, and M. Moros (2004), A highly unstable Holocene climate in the subpolar North Atlantic: Evidence from diatoms, Quat. Sci. Rev., 23, 2155-2166.

Anderson, T. R. (2005), Plankton functional type modelling: Running before we can walk?, J. Plankton. Res., 27, 1073-1081.

Archer, D., et al. (1997), A meeting place of great ocean currents: Shipboard observations of a convergent front at $2^{\circ} \mathrm{N}$ in the Pacific, Deep Sea Res., Part II, 44, 827-849.

Baldauf, J. G., and J. A. Barron (1990), Evolution of biosiliceous sedimentation patterns - Eocene through Quaternary: Palaeoceanographic response to Polar cooling, in Geological History of the Polar Oceans: Arctic Versus Antarctic, edited by U. Bliel and J. Thiede, pp. 575-607, Springer, New York.

Barber, R. T., and R. L. Haedrich (1969), Gobies associated with a scattering layer off southwest Africa, Deep Sea Res., 16, 105-106.

Bathmann, U. V., R. Scharek, C. Klaas, C. D. Dubischar, and V. Smetacek (1997), Spring development of phytoplankton biomass and composition in major water masses of the Atlantic sector of the Southern Ocean, Deep Sea Res., Part II, 44, 51-67.

Belkin, I. M., and A. L. Gordon (1996), Southern Ocean fronts from the Greenwich Meridian to Tasmania, J. Geophys. Res., 101(C2), 36753696.

Belyayeva, T. V. (1968), Range and numbers of diatoms of the genus Ethmodiscus castr. in Pacific plankton and sediments, Oceanology, 8, $79-85$.

Berger, W. H. (1970), Biogenic deep-sea sediments: Fractionation by deepsea circulation, Geol. Soc. Am. Bull., 18, 1385-1402.

Berger, W. H., C. B. Lange, and M. E. Perez (2002), The early Matuyama Diatom Maximum off South Africa: A conceptual model, Mar. Geol., 180, 105-116.

Bloomer, S. F., and L. A. Mayer (1997), Core-log-seismic integration as a framework for determining the basin-wide significance of regional reflectors in the eastern equatorial Pacific, Geophys. Res. Lett., 24, 321-324.

Boden, P., and J. Backman (1996), A laminated sediment sequence from the northern North Atlantic Ocean and its climatic record, Geology, 24, 507510.

Bopp, L., P. Monfray, O. Aumont, J.-L. Dufresne, H. Le Treut, G. Madec, L. Terray, and J. C. Orr (2001), Potential impact of climate change on marine export production, Global Biogeochem. Cycles, 15, 81-99.

Bopp, L., O. Aumont, P. Cadule, S. Alvain, and M. Gehlen (2005), Response of diatoms distribution to global warming and potential implications: A global model study, Geophys. Res. Lett., 32, L19606, doi:10.1029/2005GL023653.

Boyd, P. W., C. Robinson, G. Savidge, and P. J. L. B. Williams (1995), Water column and sea-ice primary production during Austral spring in the Bellingshausen Sea, Deep Sea Res., Part II, 42, 1177-1200.

Buessler, K. O. (1998), The decoupling of production and particulate export in the surface ocean, Global Biogeochem. Cycles, 12, 297-310.

Bustillo, M. A., and M. J. L. Garcia (1997), Age, distribution and composition of diatom bearing sediments in the Guadalquiver Basin, Spain, Geobios, 30, 335-350.

Carpenter, E. J., J. P. Montoya, J. Burns, M. R. Mulholland, A. Subramaniam, and D. G. Capone (1999), Extensive bloom of a $\mathrm{N}_{2}$-fixing diatom/cyanobacterial association in the tropical Atlantic Ocean, Mar. Ecol. Prog. Ser. 185, 273-283.

Ciesielski, P. F., et al. (1998), Proceedings of the Ocean Drilling Program Initial Report, vol. 114, Ocean Drill. Program, College Station, Tex.

Cortese, G., R. Gersonde, C. D. Hillenbrand, and G. Kuhn (2004), Opal sedimentation shifts in the World Ocean over the last $15 \mathrm{Myr}$, Earth Planet. Sci. Lett., 224, 509-527.

Crosta, X., A. Shemesh, J. Etourneau, R. Yam, I. Billy, and J. J. Pichon (2005), Nutrient cycling in the Indian sector of the Southern Ocean over the last 50,000 years, Global Biogeochem. Cycles, 19, GB3007, doi:10.1029/2004GB002344.

Dawson, A. M., and N. C. Wells (1996), General catalogue of global ocean fronts, Pacific, report, 48 pp., Southampton Oceanogr. Cent., Southampton, U. K.

de Baar, H. J. W., et al. (2005), Synthesis of iron fertilization experiments; from the iron age in the age of enlightenment, J. Geophys. Res., 110, C09S16, doi:10.1029/2004JC002601. 
De La Rocha, C. R. (2006), Opal-based isotopic proxies of paleoenvironmental conditions, Global Biogeochem. Cycles, 20, GB4S09, doi:10.1029/2005GB002664.

Dickens, G. R., and J. A. Barron (1997), A rapidly deposited pennate diatom ooze in Upper Miocene Lower Pliocene sediment beneath the North Pacific polar front, Mar. Micropaleontol., 31, 177-182.

Dugdale, R. C., F. P. Wilkerson, and H. J. Minas (1995), The role of a silicate pump in driving new production, Deep Sea Res., Part I, 42, 697 719.

Dunne, J. P., J. W. Murray, M. Rodier, and D. A. Hansell (2000), Export flux in the western and central equatorial Pacific, Deep Sea Res., Part I, 47, 901-936.

Friedrichs, M. A. M., and E. E. Hoffmann (2001), Physical control of biological processes in the central equatorial Pacific Ocean, Deep Sea Res., Part I, 48, 1023-1069.

Gardner, J. V., and L. H. Burckle (1975), Upper Pleistocene Ethmodiscus rex oozes from the eastern equatorial Atlantic, Micropaleontology, 21 , $236-242$

Gingele, F. X., and F. Schmieder (2001), Anomalous South Atlantic lithologies confirm global scale of unusual mid-Pleistocene climate excursion, Earth Planet. Sci. Lett., 186, 93-101.

Goldman, J. C. (1988), Spatial and temporal discontinuities of biological processes in pelagic surface waters, in Towards a Theory on BiologicalPhysical Interactions in the World Ocean, edited by B. J. Rothschild, pp. 273-296, Springer, New York

Goldman, J. C. (1993), Potential role of large oceanic diatoms in new primary production, Deep Sea Res., Part I, 40, 159-168.

Goldman, J. C., and D. J. McGillicuddy Jr. (2003), Effect of large marine diatoms growing at low light on episodic new production, Limnol. Oceanogr., 48, 1176-1182.

Gombos, A. M. (1984), Late Neogene diatoms and diatom oozes in the central South Atlantic, Initial Rep. Deep Sea Drill. Proj., 73, 487-494.

Grigorov, I., R. B. Pearce, and A. E. S. Kemp (2002), Southern Ocean laminated diatom ooze: Mat deposits and potential for palaeo-flux studies, ODP Leg 177, Site 1093, Deep Sea Res., Part II, 49, 3391-3407.

Guillard, R. R. L., and P. Kilham (1978), The ecology of marine planktonic diatoms, in The Biology of Diatoms, Bot. Monogr., vol. 13, edited by D. Werner, pp. 372-469, Univ. of Calif. Press, Berkeley.

Hallegraef, G. M. (1986), Taxonomy and morphology of the marine planktonic diatoms Thalassionema and Thalassiothrix, Diatom Res., 1, 57-80.

Hamm, C. E., R. Merkel, O. Springer, P. Jurkojc, C. Maier, K. Prechtel, and V. Smetacek (2003), Architecture and material properties of diatom shells provide effective mechanical protection, Nature, 421, 841-843.

Honjo, S., J. Dymond, R. Collier, and S. J. Manganini (1995), Export production of particles to the interior of the equatorial Pacific Ocean during the 1992 EqPac experiment, Deep Sea Res., Part II, 42, 831870 .

Hood, R. R., et al. (2006), Pelagic functional group modelling: Progress, challenges and prospects, Deep Sea Res., Part II, 53, 459-512.

Iriarte, J. L., and G. A. Fryxell (1995), Micro-phytoplankton at the Equatorial Pacific $\left(140^{\circ} \mathrm{W}\right)$ during the JGOFS EqPac Time Series studies: March to April and October 1992, Deep Sea Res., Part II, 42, 559-583.

Karsten, G. (1905), Das Phytoplankton des Antarktischen Meeres nach dem Material der Deutschen Tiefsee-Expedition (1898-1899), Gustav Fischer, Jena, Germany.

Kemp, A. E. S. (1994), Laminated sediments from coastal and open ocean upwelling zones: What variability do they record?, in Upwelling in the Ocean: Modern Processes and Ancient Records, edited by C. P. Summerhayes et al., pp. 239-257, John Wiley, Hoboken, N. J.

Kemp, A. E. S., and J. G. Baldauf (1993), Vast Neogene laminated diatom mat deposits from the eastern equatorial Pacific Ocean, Nature, 362 , $141-144$

Kemp, A. E. S., J. G. Baldauf, and R. B. Pearce (1995), Origins and paleoceanographic significance of laminated diatom ooze from the eastern equatorial Pacific Ocean [ODP Leg 138], Proc. Ocean Drill. Program Sci. Results, 138, 641-645.

Kemp, A. E. S., R. B. Pearce, I. Koizumi, J. Pike, and S. J. Rance (1999), The role of mat forming diatoms in formation of the Mediterranean sapropels, Nature, 398, 57-61

Kemp, A. E. S., J. Pike, R. B. Pearce, and C. B. Lange (2000), The "fall dump": A new perspective on the role of a shade flora in the annual cycle of diatom production and export flux, Deep Sea Res., Part II, 47, 21292154.

Klaas, C., S. Kuhn, S. Menden-Deuer, T. Reynarson, and V. Smetacek (1997), Phytoplankton and Heterotrophic protist counts, Ber. Polarforsch., 221, 68-71.

Kopczynska, E. E., F. Dehairs, M. Elskens, and S. Wright (2001), Phytoplankton and microzooplankton variability between the Subtropical and
Polar Fronts south of Australia: Thriving under regenerative and new production in late summer, J. Geophys. Res., 106, 31,597-31,609.

Lange, C. B., U. F. Treppke, and G. Fisher (1994), Seasonal diatom fluxes in the Guinea Basin and their relationships to trade winds, hydrography and upwelling events, Deep Sea Res., Part I, 41, 859-878.

Lange, C. B., W. H. Berger, H.-L. Lin, and G. Wefer (1999), The early Matuyama Diatom Maximum off SW Africa, Benguela Current System (ODP Leg 175), Mar: Geol., 161, 93-114.

Le Quéré, C., et al. (2005), Ecosystem dynamics based on plankton functional types for global ocean biogeochemistry models, Global Change Biol., 11, 2016-2040.

Manabe, S., and R. J. Stoufer (1993), Century-scale effects of increased atmospheric $\mathrm{CO}_{2}$ on the ocean-atmosphere system, Nature, 364, 215-218.

Margalef, R. (1978), Life-forms of phytoplankton as survival alternatives in an unstable environment, Oceanol. Acta, 1, 493-509.

Menkes, C. E., et al. (2002), A whirling ecosystem in the equatorial Atlantic, Geophys. Res. Lett., 29(11), 1553, doi:10.1029/2001GL014576.

Mikkelsen, N. (1977), On the origin of Ethmodiscus ooze, Mar. Micropaleontol., 2, 35-46.

Miller, C. B. (2004), Biological Oceanography, Blackwell, Malden, Mass.

Moore, J. K., and T. A. Villareal (1996), Buoyancy and growth characteristics of three positively buoyant marine diatoms, Mar. Ecol. Prog. Ser. $132,203-213$.

Mortlock, R. A., and P. N. Froelich (1989), A simple method for the rapid determination of biogenic opal in marine sediments, Deep Sea Res., 36, $1415-1426$

Murray, J. W., E. Johnson, and C. Garside (1995), A U.S. JGOFS Process Study in the equatorial Pacific (EqPaq): Introduction, Deep Sea Res., Part II, 42, 275-293.

Naveiro Garabato, A. C., J. T. Allen, H. Leach, V. H. Strass, and R. T. Pollard (2001), Mesoscale subduction at the Antarctic Polar Front driven by baroclinic instability, J. Phys. Oceanogr., 31, 2087-2107.

Naveiro Garabato, A. C., V. H. Strass, and G. Kattner (2002), Fluxes of nutrients in a three dimensional meander structure of the Antarctic Polar Front, Deep Sea Res., Part II, 49, 3771-3792.

Nelson, D. M., P. Tréguer, M. A. Brzezinski, A. Leynaert, and B. Quéguiner (1995), Production and dissolution of biogenic silica in the ocean: Revised global estimates, comparison with regional data and relationship to biogenic sedimentation, Global Biogeochem. Cycles, 9, 359-372.

Orsi, A. H., T. Whitworth III, and W. D. Nowlin Jr. (1995), On the meridional extent of the Antarctic Circumpolar Current, Deep Sea Res., Part $I, 42,641-673$

Parslow, J. S., P. W. Boyd, S. R. Rintoul, and F. B. Griffiths (2001), A persistent subsurface chlorophyll maximum in the Interpolar Frontal Zone south of Australia: Seasonal progression and implications for phytoplankton-light-nutrient interactions, J. Geophys. Res., 106, 31,54331,557 .

Pearce, R. B., A. E. S. Kemp, J. G. Baldauf, and S. C. King (1995), High resolution sedimentology and micropaleontology of laminated diatomaceous sediment from the eastern equatorial Pacific Ocean (ODP Leg 138), Proc. Ocean Drill. Program Sci. Results, 138, 647-663.

Pike, J. (2000), Backscattered electron image analysis of Early Pliocene laminated Ethmodiscus ooze, Site 1010, Proc. Ocean Drill. Program Sci. Results, 167, 207-212.

Pilskaln, C. H., T. A. Villareal, M. Dennett, C. Darkangelo-Wood, and G. Meadows (2005), High concentrations of marine snow and diatom algal mats in the North Pacific Subtropical Gyre: Implications for carbon and nitrogen cycles in the oligotrophic ocean, Deep Sea Res., Part I, 52, 2315-2332.

Pollard, R. T., M. I. Lucas, and J. F. Read (2002), Physical controls on biogeochemical zonation in the Southern Ocean, Deep Sea Res., Part II, 49, 3289-3305.

Pondaven, P., O. Rageuneau, P. Tréguer, A. Hauvespre, L. Dezileau, and J. L. Reyss (2000), Resolving the "opal paradox" in the Southern Ocean, Nature, 405, 168-172.

Prahl, F. G., B. N. Popp, and J. E. Valdez-Holguin (2005), Nitrogen fixation in summertime surface waters of the Guaymas Basin, Gulf of California Eos Trans. $A G U, 86(52)$, Fall Meet. Suppl., Abstract OS34A-04.

Quéguiner, B. (2001), Biogenic silica production in the Australian sector of the Subantarctic Zone of the Southern Ocean in late Summer 1998 , J. Geophys. Res., 106, 31,627-31,636.

Quéguiner, B., P. Tréguer, I. Peeken, and R. Scharek (1997), Biogeochemical dynamics and the silicon cycle in the Atlantic sector of the Southern Ocean during austral spring 1992, Deep Sea Res., Part II, 44, 69-89.

Quilty, P. G., K. R. Kerry, and H. J. Marchant (1985), A seasonally recurrent patch of Antarctic planktonic diatoms, Search, 16(1-2), 48-51.

Rea, D. K., and T. R. Janecek (1981), Mass accumulation rates of the nonauthigenic, inorganic crystalline (eolian) component of deep-sea sedi- 
ments from the western mid-Pacific Mountains, Deep Sea Drilling Project Site 463, in Initial Reports DSDP 62, edited by J. Thiede et al., pp. $653-$ 659, U.S. Gov. Print. Off., Washington, D. C.

Romero, O., and F. Schmieder (2006), Occurrence of thick Ethmodiscus oozes associated with a terminal Mid-Pleistocene Transition event in the oligotrophic subtropical South Atlantic, Palaeogr. Palaeoclimatol. Palaeoecol., 235, 321-329.

Sachs, J. P., and D. J. Repeta (1999), Oligotrophy and nitrogen fixation during eastern Mediterranean sapropel events, Science, 286, 2485-2488.

Sancetta, C. (1999), The mystery of the sapropels, Nature, 398, 27-28.

Sancetta, C., T. Villareal, and P. Falkowski (1991), Massive fluxes of rhizosolenid diatoms-A common occurrence?, Limnol. Oceanogr., 36 , $1452-1457$.

Sarmiento, J. L., T. M. C. Hughes, R. J. Stoufer, and S. Manabe (1988), Simulated response of the ocean carbon cycle to anthropogenic climate warming, Nature, 393, 245-249.

Sarthou, G., K. R. Timmermans, S. Blain, and P. Tréguer (2005), Growth physiology and fate of diatoms in the ocean, J. Sea Res., 53, 25-42.

Scharek, R., L. M. Tupas, and D. M. Karl (1999), Diatom fluxes to the deep sea in the oligotrophic North Pacific gyre at Station ALOHA, Mar. Ecol. Prog. Ser., 182, 55-67.

Schlitzer, R. (2002), Carbon export fluxes in the Southern Ocean: Results from inverse modelling and comparison with satellite-based estimates, Deep Sea Res., Part II, 49, 1623-1644.

Shipboard Scientific Party (1999), Leg 177 summary: Southern Ocean Paleoceanography, Proc. Ocean Drill. Program Initial Rep., 177, 1-67.

Shipboard Scientific Party (2005), North Atlantic climate: Ice sheet-ocean atmosphere interactions on millennial timescales during the late $\mathrm{Neo}-$ gene-Quaternary using a paleointensity-assisted chronology for the North Atlantic, Integrated Ocean Drill. Program Prelim. Rep. 303, 51 pp., Ocean. Drill. Program, College Station, Tex.

Sigmon, D. E., D. M. Nelson, and M. A. Brzezinski (2002), The Si cycle in the Pacific sector of the Southern Ocean: Seasonal diatom production in the surface layer and export to the deep sea, Deep Sea Res., Part II, 49, $1747-1763$.

Singler, H. R., and T. A. Villareal (2005), Nitrogen inputs into the euphotic zone by vertically migrating Rhizosolenia mats, J. Plankton Res., 27, $545-556$

Smetacek, V. S. (2000), The giant diatom dump, Nature, 406, 574-575.

Smetacek, V. S., C. Klaas, S. Menden-Deuer, and T. A. Rynearson (2002), Mesoscale distribution of dominant diatom species relative to the hydrographical field along he Antarctic Polar Front, Deep Sea Res., Part II, 49 , $3835-3848$

Smetacek, V., P. Assmy, and J. Henjes (2004), The role of grazing in structuring Southern Ocean pelagic ecosystems and biogeochemical cycles, Antarct. Sci., 16, 541-558.

Smith, C. R., D. J. Hoover, S. E. Doan, R. H. Pope, D. J. Demaster, F. C. Dobbs, and M. A. Altabet (1996), Phytodetritus at the abyssal seafloo across $10^{\circ}$ of latitude in the central equatorial Pacific, Deep Sea Res., Part II, 43, 1309-1338.

Snoeckx, H., D. K. Rea, C. E. Jones, and B. L. Ingram (1995), Eolian and silica deposition in the central North Pacific: Results from sites $885 / 886$, Proc. Ocean Drill. Program Sci. Res., 145, 219-230.

Sournia, A. (1982), Is there a shade flora in the marine plankton?, J. Plankton Res., 4, 391-399.
Stabell, B. (1986), Variations of diatom flux in the eastern Equatorial Atlantic during the last 400,000 years ("Meteor" cores 13519 and 13521), Mar. Geol., 72, 305-323.

Strass, V. H., et al. (2002), Mesoscale frontal dynamics: Shaping the environment of primary production in the Antarctic Circumpolar Current, Deep Sea Res., Part II, 49, 3735-3769.

Tremblay, J. E., M. I. Lucas, G. Kattner, R. Pollard, V. Strass, U. Bathmann, and A. Bracher (2002), Significance of the Polar Frontal Zone for largesized diatoms and new production during the summer in the Atlantic sector of the Southern Ocean, Deep Sea Res., Part II, 49, 3793-3811.

Villareal, T. A., M. A. Altabet, and K. Culver-Rymsza (1993), Nitrogen transport by vertically migrating diatom mats in the north Pacific Ocean, Nature, 363, 709-712

Villareal, T. A., C. Pilskaln, M. Brzezinski, F. Lipschultz, M. Dennett, and G. B. Gardner (1999a), Upward transport of oceanic nitrate by migrating diatom mats, Nature, 397, 423-425.

Villareal, T. A., L. Joseph, M. Brzezinski, R. F. Shipe, F. Lipschultz, and M. A. Altabet (1999b), Biological and chemical characteristics of the giant diatom Ethmodiscus (Bacillariophyceae) in the central North Pacific gyre, J. Phycol., 35, 896-902.

Waite, A. M., and S. D. Nodder (2001), The effect of in situ iron addition on the sinking rates and export flux of Southern Ocean diatoms, Deep Sea Res., Part II, 48, 2635-2654.

Weston, K., L. Fernand, and D. K. Mills (2005), Primary production in the deep chlorophyll maximum of the central North Sea, J. Plankton Res., 27, 909-922.

Wilson, C., T. A. Villareal, N. Maximenko, S. J. Bograd, J. P. Montoya, and C. A. Schoenbaechler (2006), Biological and physical forcings of late summer chlorophyll blooms at $30^{\circ} \mathrm{N}$ in the oligotropic Pacific, J. Mar. Syst., in press

Yoder, J. A., S. G. Ackleson, R. T. Barber, P. Flament, and W. M. Balch (1994), A line in the sea, Nature, 371, 689-692.

Zeldis, J. (2001), Mesozooplankton community composition, feeding, and export production during SOIREE, Deep Sea Res., Part II, 48, $2615-$ 2634

Zielinski, U., and R. Gersonde (1997), Diatom distribution in the southern ocean surface sediments [Atlantic sector]: Implications for paleoenvironmental reconstructions, Palaeogr. Palaeoclimatol. Palaeoecol., 129, $213-250$.

R. B. Pearce, A. E. S. Kemp, J. Rance, and I. Salter, School of Ocean and Earth Science, National Oceanography Centre, Southampton, University of Southampton, Southampton, SO14 3ZH, UK. (aesk@noc.soton.ac.uk)

I. Grigorov, Institut Universitaire Europeen de la Mer, Technopole BrestIroise, Place Copernic, F-29280 Plouzane, France.

C. B. Lange, Department of Oceanography, Center for Oceanographic Research in the Eastern South Pacific (FONDAP-COPAS), University of Concepción, Chile, P.O. Box 160-C, Chile.

P. Quilty, School of Earth Sciences, University of Tasmania, Private Bag 79, Hobart, Tasmania, Australia 7001. 